\title{
Influence of mulches on urban vegetation construction in coastal saline land under drip irrigation in North China
}

\author{
Xiulong Chen ${ }^{\mathrm{a}, \mathrm{b}}$, Yaohu Kang ${ }^{\mathrm{a}}$, Shuqin Wan ${ }^{\mathrm{a}, *}$, Xiaobin Li ${ }^{\mathrm{a}, \mathrm{b}}$, Liping Guo ${ }^{\mathrm{a}, \mathrm{b}}$ \\ ${ }^{a}$ Key Laboratory of Water Cycle and Related Land Surface Processes, Institute of Geographic Sciences and Natural Resources Research, Chinese Academy of \\ Sciences, Beijing 100101, China \\ ${ }^{\mathrm{b}}$ Graduate University of Chinese Academy of Sciences, Beijing 100049, China
}

\section{A R T I C L E I N F O}

\section{Article history:}

Received 5 November 2014

Received in revised form 24 April 2015

Accepted 5 May 2015

Available online 18 May 2015

\section{Keywords:}

Drip irrigation

Salt accumulation

Investment cost

Salt-affected soil

Urban vegetation construction

\begin{abstract}
A B S T R A C T
In order to generate information for reclaiming coastal saline sandy-loam soil for urban vegetation construction around Bohai Bay in North China, a field experiment combined with drip irrigation and setting a gravel-sand layer beneath the saline soil but above the water table was conducted to study the effect of mulches on irrigated water amount, soil salt control and willow (Salix babylonica L.) growth, and construction costs were also estimated during 2012 and 2013. The three mulch treatments were control treatment with no mulch (C1), black shading net mulch (C2) and straw mulch (C3). In order to leach salts in the soil profile, irrigation was triggered by the soil matric potential threshold at 20-cm soil depth of $-5 \mathrm{kPa}$ in the early stage, and this was changed to $-10 \mathrm{kPa}$ until the end of the first growing year, and to $-20 \mathrm{kPa}$ for the second year. The results showed that (1) the straw mulch consumed the least irrigation water, followed by the black shading net mulch and the control treatment. Compared to the control treatment, the amount of irrigation for the straw mulch had decreased by $12 \%$ in 2012 and $27 \%$ in 2013. (2) The salinity reduction was mainly related to rainfall and the strategy of drip irrigation; and the mulches, especially straw mulch, decreased the risk of salt accumulation in early spring. (3) The best growth characteristic of plants and the optimal investment cost were for straw mulch, and the high investment cost in 2012 was due to soil preparation cost and the willows, gravel and sand cost was high and then it had decreased by $90 \%$ in 2013 . From the combined points of water saving, plant growth and investment cost, the use of straw mulch with drip irrigation could aid in urban vegetation construction on coastal saline land in North China.
\end{abstract}

(C) 2015 Elsevier B.V. All rights reserved.

\section{Introduction}

With the rapid social-economic development in coastal area along Bohai Sea in North China, more and more people move to these areas to seek better opportunities and higher standards of living. The role of urban vegetation to improve environmental quality, increase the economic, physical and social health of communities is important to quality of life (McPherson et al., 2000; Wu et al., 2009). However, in these coastal areas, the soil salinity is high (15-65 $\mathrm{dS} \mathrm{m}^{-1}$ ), with two dominant ions (sodium and chlorine) from sea water (Sun et al., 2013), the groundwater table is shallow (0.8-1.5 m) (Wang et al., 1993; Xing et al., 2013), and windy conditions in spring and winter lead to high evaporation and salt accumulation on the soil surface. In addition, fresh water resource is very limited (Xia, 2002; Zhang et al., 2011). So the construction

\footnotetext{
* Corresponding author. Tel.: +86 1064889586

E-mail address: wansq@igsnrr.ac.cn (S. Wan).
}

of urban vegetation in these coastal areas was restricted by the high salt content in soil and fresh water shortage. But, considering a mean annual precipitation of about $560-916 \mathrm{~mm}$ in the coastal areas of Bohai Sea (Marine Geology Research Center, Institute of Oceanology, CAS), rainfall is ideal alternative fresh water in coastal regions.

Drip irrigation can apply water precisely and uniformly, leach salts to the fringe of wetted areas, maintain relatively suitable soil water conditions for plant growth and has been confirmed as an effective technology in saline soil reclamation (Goldberg et al., 1976; Bresler et al., 1982; Kang et al., 2008; Hanson et al., 2009). Numerous recent studies have found that different extremely saline soils gradually become moderately saline after $2-3$ years of cultivation with scheduled irrigation using a set threshold of soil matric potential (SMP, Jiao et al., 2008; Liu et al., 2011; Wang et al., 2011), and higher SMP treatments have a more evident leaching effect. Wan et al. (2012) found that the irrigation amount decreased significantly as the SMP decreased from -5 to $-25 \mathrm{kPa}$, and the study recommended a SMP threshold of around $-10 \mathrm{kPa}$ within the first 
1-2 years, and then decreased to around $-20 \mathrm{kPa}$ in the following years, dependent upon salt leaching efficiency, could be used to reclaim the salt-affected soil. The similar result provided by Zhang et al. (2013). Sun et al. (2012a, 2013) found that controlling the SMP above $-5 \mathrm{kPa}$ and setting a gravel-sand layer beneath saline soil but above the water table were two useful strategies to reclaim coastal saline soil for vegetation construction.

Mulches can reduce evaporation, delay salt accumulation near the soil surface, increase soil temperature, control weeds and promote plant growth (Kimber, 1973; Ossom et al., 2001; Ramakrishna et al., 2006; Terasaki et al., 2009; Zhao et al., 2014; Aragues et al., 2014). Compared with bare saline land, mulches can store more precipitation and irrigation water in soil and the higher soil water content under mulches can enhance salt leaching by subsequent rains (Adams, 1966; Doring et al., 2005).

Therefore, the objectives of this study were: (1) to evaluate the effects of mulch practices combined with drip irrigation on the irrigation water amount, salt control, plant growth and investment costs and (2) to provide the strategies for urban vegetation construction on coastal saline land in North China.

\section{Materials and methods}

\subsection{Experimental site}

Field experiments were conducted during 2012 and 2013 on a coastal saline wasteland in the Caofeidian Industrial Zone $\left(39^{\circ} 01^{\prime} 54^{\prime \prime} \mathrm{N}, 118^{\circ} 28^{\prime} 38^{\prime \prime} \mathrm{E}\right)$, southeast of Tangshan city and northeast of the Bohai Bay, China. The study area has a temperate semi-humid monsoon climate with a mean annual precipitation of $607 \mathrm{~mm}$, and most rainfall falls during June-September. Average evaporation is $1900 \mathrm{~mm}$ and seasonal winds and droughts are frequent in spring, autumn and winter. The soil was a sandy loam. The average soil texture in the $0-100 \mathrm{~cm}$ soil layer was sandy loam, with particle size distribution for $<0.002$, $0.002-0.05$ and $>0.05 \mathrm{~mm}$ of $0.45,43.15$ and $56.39 \%$, respectively. The electrical conductivity (ECe), $\mathrm{pH}$ and sodium adsorption ratio (SAR) of the saturated soil extracts taken from the initial soil profile were in the ranges of $24.8-26.8 \mathrm{dS} \mathrm{m}^{-1}, 7.6-7.6$ and 35.7-38.3 $\left(\mathrm{mmol} \mathrm{L}^{-1}\right)^{0.5}$, respectively. The soil bulk density was $1.60-1.74 \mathrm{~g} \mathrm{~cm}^{-3}$ and the groundwater table was $0.8 \mathrm{~m}$ below the surface. Detailed information on the initial soil profile is shown in Table 1.

\subsection{Plant management and experimental design}

\subsubsection{Soil preparation and plant management}

The soil in the experimental area $(54 \mathrm{~m} \times 24 \mathrm{~m})$ was first deepplowed to a depth of $60 \mathrm{~cm}$ using an excavator on 10 May 2012. During 20-21 May 2012, the soil was removed to a depth of $60 \mathrm{~cm}$ and a $15-\mathrm{cm}$ thick gravel layer was placed at the bottom. This was then covered with a $5-\mathrm{cm}$ thick layer of sand and then $100-\mathrm{cm}$ of native saline soil was placed above the sand (Fig. 1A), similar to a previous study (Sun et al., 2013). Two 110-cm diameter polyvinylchloride pipes were used to connect the gravel-sand layer with a drainage ditch. When the soil preparation had finished, the surface of the experimental soil was about $60 \mathrm{~cm}$ higher than the surrounding area. Several small drainage ditches were then dug around the experimental area to provide drainage for runoff. The experimental area was divided into 12 experimental treatment plots. The soil bulk density was $1.69-1.72 \mathrm{~g} \mathrm{~cm}^{-3}$ before the soil was deep-plowed and decreased to $1.48-1.52 \mathrm{~g} \mathrm{~cm}^{-3}$ after deep-plowing.

The experimental material was willow (Salix babylonica L.), a salt-tolerant plant with salt threshold values of $6-8 \mathrm{dS} \mathrm{m}^{-1}$ (Maas, 1986). The willows were transplanted on 24 May 2012. There were 144 plants in the whole experiment area, and the area was transplanted into five rows with $3 \mathrm{~m}$ between rows and 3-m intervals within rows. Each plant was transplanted into a hole bigger than the root ball, and then non-saline sandy soil was placed in the space between the root ball and the saline soil (Fig. 1A). A similar method was used in a previous study (Zhang et al., 2013). After all willows transplanted, all plants were fixed by wooden poles (length of about $1.4 \mathrm{~m}$ and stem diameter of $4-6 \mathrm{~cm}$, four poles per willow) in order to against the wind. The experiment lasted from 24 May 2012 to the end of 2013. The survival rate, plant height, stem diameters and average crown diameters were measured simultaneously on 25 October 2013. An automatic weather station was installed on 23 May 2012 to monitor the rainfall, temperature, humidity, and wind speed and direction.

\subsubsection{Experiment design}

Three mulch treatments were set up to determine the optimal cover material for willow growth on this coastal saline soil: control treatment without mulch (C1), black shading net (C2) and straw (C3) mulches. Each treatment was replicated four times in a completely randomized block design and each plot was $9 \mathrm{~m} \times 12 \mathrm{~m}$ in size. With salt leaching, weeds grew naturally in the $\mathrm{C} 1$ treatment plots and were not controlled by human activity in both growing seasons. Black shading net was chosen as mulch material because it is easy to purchase in the market and simple to lay on the soil surface; and allows rainfall pass through the material into soil. Two layers of black shading net (light intensity was reduced by $90 \%$ ) covered the $\mathrm{C} 2$ treatment plots. Rice straw at $12,000 \mathrm{~kg} \mathrm{ha}^{-1}$ was used in the $\mathrm{C} 3$ treatment plots, and was easy to get from the surrounding area at a low price. During two growing years, the weeds were regular weeded out from both $\mathrm{C} 2$ and $\mathrm{C} 3$ treatment plots. Irrigation water was taken from a 300-m deep motor-pumped well with a mean electrical conductivity (EC) of $0.63 \mathrm{dS} \mathrm{m}^{-1}$, mean $\mathrm{pH}$ of 8.2 and SAR of $3.8\left(\mathrm{mmol} \mathrm{L}^{-1}\right)^{0.5}$.

\subsubsection{Irrigation}

After willows were transplanted (24 May 2012), all experiment zones were uniformly irrigated with a high intensity of drip irrigation without mulching in the first $5 \mathrm{~d}$ to rapidly wet the whole soil

Table 1

The physical properties of soil, electrical conductivity of the saturated paste extracts (ECe), SAR and pH values of the initial soil profile.

\begin{tabular}{|c|c|c|c|c|c|c|c|c|}
\hline \multirow[t]{2}{*}{ Soil layers (cm) } & \multicolumn{3}{|c|}{ Soil mechanical composition (\%) } & \multirow[t]{2}{*}{ Soil texture } & \multirow[t]{2}{*}{ Soil bulk density $\left(\mathrm{g} \mathrm{cm}^{-3}\right)$} & \multirow[t]{2}{*}{$\mathrm{ECe}\left(\mathrm{dS} \mathrm{m}^{-1}\right)$} & \multirow[t]{2}{*}{$\operatorname{SAR}\left(\mathrm{mmol} \mathrm{L}^{-1}\right)^{0.5}$} & \multirow[t]{2}{*}{$\mathrm{pH}$} \\
\hline & $<0.002 \mathrm{~mm}$ & $0.002-0.05 \mathrm{~mm}$ & $0.05-2.0 \mathrm{~mm}$ & & & & & \\
\hline $0-10$ & 0.25 & 40.90 & 58.85 & Sandy loam & 1.74 & 26.0 & 37.2 & 7.6 \\
\hline $10-20$ & 0.51 & 42.67 & 56.82 & Sandy loam & 1.74 & 26.1 & 37.4 & 7.6 \\
\hline $20-30$ & 0.42 & 44.70 & 54.89 & Sandy loam & 1.69 & 26.8 & 38.3 & 7.6 \\
\hline $30-40$ & 0.45 & 47.44 & 52.11 & Sandy loam & 1.70 & 26.3 & 37.7 & 7.6 \\
\hline $40-60$ & 0.36 & 42.46 & 57.18 & Sandy loam & 1.69 & 24.8 & 35.7 & 7.6 \\
\hline $60-80$ & 0.49 & 41.39 & 58.12 & Sandy loam & 1.68 & 26.7 & 38.3 & 7.6 \\
\hline $80-100$ & 0.60 & 45.10 & 54.31 & Sandy loam & 1.60 & 26.3 & 37.7 & 7.6 \\
\hline Average & 0.45 & 43.15 & 56.39 & Sandy loam & 1.69 & 26.1 & 37.4 & 7.6 \\
\hline
\end{tabular}


(A)

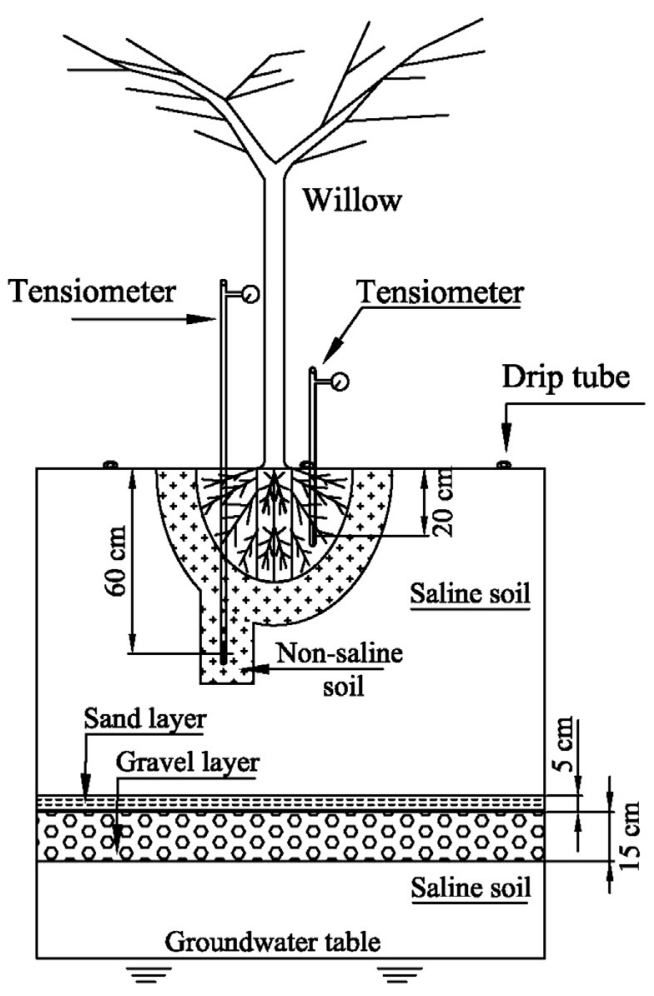

(B)

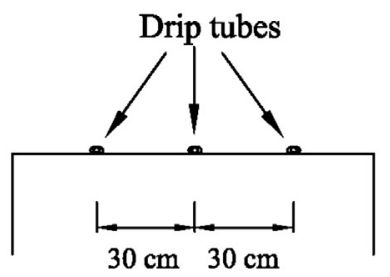

(C)

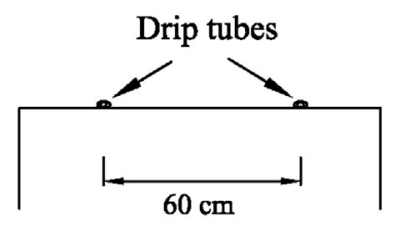

(D)

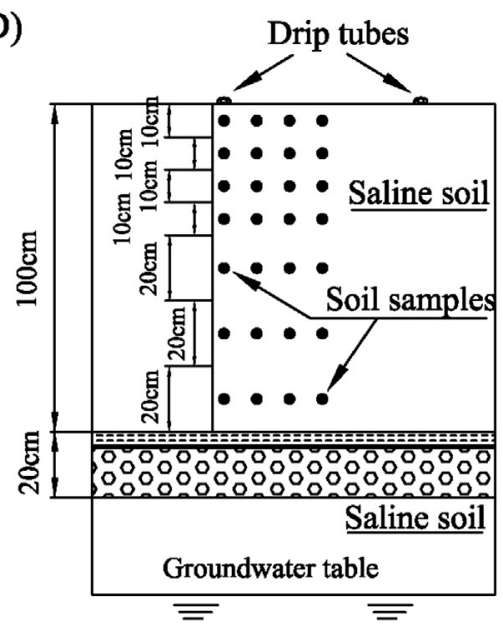

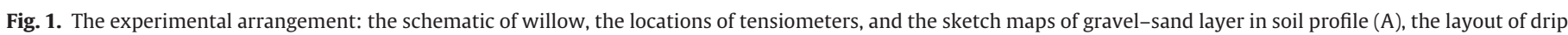
tubes in the first irrigation stage (B), the layout of drip tubes after the first irrigation stage (C) and the positions of soil samples (D).

layer and accelerate salt leaching during the early growth period. In these $5 \mathrm{~d}$, the emitter discharge rate was controlled at $1.2 \mathrm{Lh}^{-1}$ and the distances between two adjacent drip tubes were $30 \mathrm{~cm}$ (Fig. 1B) and two adjacent emitters were $20 \mathrm{~cm}$. During these $5 \mathrm{~d}$, all plots had two tensiometers installed to monitor SMP at 20 and $60 \mathrm{~cm}$ depths below the emitter nearby a plant (Fig. 1A). The initial soil was dry and when SMP at $20 \mathrm{~cm}$ depth exceeded $-5 \mathrm{kPa}$, irrigation was stopped. Then when the SMP value decreased below $-5 \mathrm{kPa}, 10 \mathrm{~mm}$ of water was irrigated uniformly in all plots. The SMP tensiometer recordings for each treatment were made every $2 \mathrm{~h}$ during daytime in order to determine the appropriate water application time. According to the record, the soil was wetted with about $60 \mathrm{~mm}$ of water on 25 May and then with about $30 \mathrm{~mm}$ on 26 May. A further 20,20 and $10 \mathrm{~mm}$ were applied by drip irrigation on 27, 28 and 29 May, respectively. So there was $140 \mathrm{~mm}$ of water irrigated in these 5 days. After the first $5 \mathrm{~d}$, all experiment plots were irrigated uniformly to ensure survival of all plants. The distance between two drip tubes was changed to $60 \mathrm{~cm}$ (Fig. 1C). When the SMP value of any one of two tensiometers at the 20 and $60 \mathrm{~cm}$ depths decreased below $-5 \mathrm{kPa}$, the irrigation water was supplied by drip irrigation with $10 \mathrm{~mm}$ per irrigation time. The SMP tensiometers recordings for each treatment were made twice daily (8:00 and 17:00). Until all willows grew uniform (1 July 2012), $50 \mathrm{~mm}$ of irrigation water was applied.
The period from the willows transplanted to all plants grew uniform was named the uniform irrigation period, and $190 \mathrm{~mm}$ of irrigation water was applied to all treatment plots during this period.

When all the willows had maintained uniform growth, the whole experiment zone was divided into 12 plots for three mulch treatments. Each treatment was irrigated independently by a valve controlling the drip irrigation and an independent tensiometer in each treatment was installed at $20 \mathrm{~cm}$ depth to monitor the SMP. The SMP was changed to maintain $-10 \mathrm{kPa}$. When the SMP of any treatment fell below $-10 \mathrm{kPa}, 10 \mathrm{~mm}$ of water was applied to the treatment. When the salt in the whole soil profile had leached to below the salt threshold of willow, the SMP of all treatments was adjusted to $-20 \mathrm{kPa}$ to promote root growth downward. During early spring (spring irrigation period on 3-5 April 2014) and late winter (winter irrigation periods on 1-3 December 2013 and 4-6 December 2014), the water irrigation amount for all treatments was increased from the normal amount of $10-40 \mathrm{~mm}$.

Urea (44\% nitrogen) and potassium dihydrogen phosphate (54\% phosphate and 32\% potassium) were applied by addition to the irrigation water; over the entire experimental period, the total amounts were about 73 and $59 \mathrm{~kg} \mathrm{ha}^{-1}$ per year, respectively. 
Table 2

The number of irrigations, amount of applied water and rainfall for each treatment during the willow growing seasons in 2012 and 2013.

\begin{tabular}{|c|c|c|c|c|c|c|c|c|c|}
\hline \multirow[t]{2}{*}{ Years } & \multirow[t]{2}{*}{ Treatment } & \multicolumn{2}{|c|}{$\begin{array}{l}\text { The uniform irrigation } \\
\text { period }(\mathrm{mm})\end{array}$} & \multirow[t]{2}{*}{$\begin{array}{l}\text { Irrigation in the winter } \\
\text { and spring }(\mathrm{mm})\end{array}$} & \multicolumn{3}{|c|}{ During treatment } & \multirow[t]{2}{*}{$\begin{array}{l}\text { Total amount of } \\
\text { irrigation }(\mathrm{mm})\end{array}$} & \multirow[t]{2}{*}{$\begin{array}{l}\text { Total irrigation vs the } \\
\text { C1 treatment (\%) }\end{array}$} \\
\hline & & $\begin{array}{l}\text { Irrigation } \\
(\mathrm{mm})\end{array}$ & $\begin{array}{l}\text { Rainfall } \\
(\mathrm{mm})\end{array}$ & & $\begin{array}{l}\text { Number of } \\
\text { irrigations }\end{array}$ & $\begin{array}{l}\text { Irrigation } \\
(\mathrm{mm})\end{array}$ & $\begin{array}{l}\text { Rainfall } \\
(\mathrm{mm})\end{array}$ & & \\
\hline \multirow{3}{*}{2012} & $\mathrm{C} 1$ & 190 & 210 & 40 & 20 & 200 & 697 & 430 & 100 \\
\hline & $\mathrm{C} 2$ & 190 & 210 & 40 & 18 & 180 & 697 & 410 & 95 \\
\hline & $\mathrm{C} 3$ & 190 & 210 & 40 & 15 & 150 & 697 & 380 & 88 \\
\hline \multirow{3}{*}{2013} & $\mathrm{C} 1$ & & & 80 & 25 & 250 & 590 & 330 & 100 \\
\hline & $\mathrm{C} 2$ & & & 80 & 20 & 200 & 590 & 280 & 85 \\
\hline & $\mathrm{C} 3$ & & & 80 & 16 & 160 & 590 & 240 & 73 \\
\hline
\end{tabular}

Total amount of irrigation $(\mathrm{mm})=$ irrigation during the uniform irrigation period $(\mathrm{mm})+$ irrigation in the winter and spring $(\mathrm{mm})+$ irrigation during treatment $(\mathrm{mm})$.

\subsection{Soil sample observation and analysis}

\subsubsection{Soil sample analysis}

Soil samples were taken from each plot with an auger $(3.0 \mathrm{~cm}$ diameter and $10 \mathrm{~cm}$ height) before willow was established (23 May 2012), after the uniform irrigation finished (1 July 2012), at the end of 2012 (2 November 2012), at the beginning of 2013 (20 March 2013) and at the end of 2013 (2 November 2013). Moreover, the soil samples obtained on 1 July 2012 also represented the soil condition before mulch treatments.

The samples were taken at $0,10,20$ and $30 \mathrm{~cm}$ distance from the emitters and the sampling depths were $0-10,10-20,20-30,30-40$, $40-60,60-80$ and $80-100 \mathrm{~cm}$ (Fig. 1D). All the soil samples were airdried and passed through a $1-\mathrm{mm}$ sieve. The soluble salt estimates, soil $\mathrm{pH}$ and the SAR were calculated from saturated soil extracts. ECe and $\mathrm{pH}$ were determined using a conductivity meter (DDS-11, REX, Shanghai) and a pH meter (PHS-3C, REX), respectively. The $\mathrm{Ca}^{2+}$ and $\mathrm{Mg}^{2+}$ were measured using the EDTA titration method and $\mathrm{Na}^{+}$by flame photometry as described by Bao (2000). The SAR of the saturated paste extract was calculated as follows:

$\mathrm{SAR}=\frac{\left[\mathrm{Na}^{+}\right]}{\left(\left[\mathrm{Ca}^{2+}\right]+\left[\mathrm{Mg}^{2+}\right]\right)^{0.5}}$

where the concentration of each cation is in $\mathrm{mmol} \mathrm{L}^{-1}$.

In this experiment, the mean ECe values for the root zone $(0-60 \mathrm{~cm})$ and the whole soil profile $(0-100 \mathrm{~cm})$ were integrated to account for both the spatial and temporal variations.

The average ECe value in the soil profile on date $i$ was calculated as follows:

$\mathrm{ECe}(i)=\frac{\sum_{k=10,20,30,40,60,80,100(10,20,30,40)}^{j=0,10,20.30} \operatorname{ECe}(i, j, k) * S(j, k)}{\sum_{k=10,20,30,40,60,80,100(10,20,30,40)}^{j=0,10,20.30} S(j, k)}$

where $\mathrm{ECe}(i, j, k)$ is the ECe value of the soil sample on date $i$, where $j$ is the horizontal distance from the drip line and $k$ is the soil depth. $S(j, k)$ is the area represented by the soil sample.

The desalinization rate was calculated as follows:

$\operatorname{ECe}(d)=\frac{E \bar{C}(\iota)-E C e(\bar{\imath}+1)}{E C \bar{e}(\iota)} \%$

where ECe $(i)$ and ECe $(i+1)$ refer to the spatial weighted mean value of the soil profile on the previous stage and later stage during salt leaching.

The mean $\mathrm{pH}$ and SAR in the root zone $(0-60 \mathrm{~cm})$ and for the whole soil profile $(0-100 \mathrm{~cm})$ were calculated as the weighted mean in a similar way to ECe.

\subsection{Statistical analysis}

General linear model (GLM) method of ANOVA was conducted to evaluate the main effects of factors on soil salinity in root zone $(0-60 \mathrm{~cm})$ and whole soil profile $(0-120 \mathrm{~cm})$. Two factors, mulch ( $n=3$, i.e. control treatment, black shading net mulch and straw mulch), sampling time ( $n=2$, i.e. at the end of 2012, and at the end of 2013) were included. The ECe values in experimental zone of three treatments were different after the uniform irrigation stage, so covariance analysis with the ECe value as covariates was carried out. Analysis of variance (ANOVA) was conducted to evaluate the effects of the factor (mulch) on the change of soil salinity after a winter (from 2 November 2012 to 20 March 2013), the stem diameter, plant height, and survival ratio of willows at the end of the experiment, and investment cost in 2 years. The multiple comparisons were done for significant effects among treatments with the Fisher's least-significant-difference (LSD) test. The significance level was set at $p<0.05$. The statistical software used was SPSS 13.0. Software of Surfer 8.0 was used to create the figures of spatial distribution of soil salinity (ECe).

\section{Results and discussion}

\subsection{Precipitation}

The rainfall data during the growing seasons of 2012 and 2013 are shown in Fig. 2. The total rainfall was $907 \mathrm{~mm}$ in 2012 (from 23 May to 27 December) and $590 \mathrm{~mm}$ in 2013. About 79 and $86 \%$ of total rainfall was concentrated in June-September in 2012 and 2013, respectively. There were 26 and 15 effective rainfall (>10 $\mathrm{mm} \mathrm{d}^{-1}$ ) events in 2012 and 2013, respectively. The detailed information was four torrential rain events (rainfall intensity $>50 \mathrm{~mm} \mathrm{~d}^{-1}$ ), nine and zero heavy rainfall events (rainfall intensity $<50$ and $>25 \mathrm{~mm} \mathrm{~d}^{-1}$ ) and 13 and 10 drizzle events (rainfall intensity $<25$ and $>10 \mathrm{~mm} \mathrm{~d}^{-1}$ ) in 2012 and 2013, respectively. The rainfall before 23 May 2012 was not recorded because the automatic weather station was not installed. The rainfall in 2012 and 2013 represented a wet and a normal year, respectively.

In the uniform irrigation stage, there was $210.0 \mathrm{~mm}$ of rainfall (23 and $187 \mathrm{~mm}$ occurred in the first five days and the later irrigation stage, respectively). During mulch treatment period, the rainfall was $697 \mathrm{~mm}$ and $590 \mathrm{~mm}$ for the first and second year, respectively (Table 2 ).

\subsection{SMP control and irrigation management}

\subsection{1. $S M P$}

The SMP immediately under the emitters at $20 \mathrm{~cm}$ depth was well controlled above $-5 \mathrm{kPa}$ in the uniform irrigation period during June 2012, above $-10 \mathrm{kPa}$ for July-November 2012, and above $-20 \mathrm{kPa}$ in 2013 (Fig. 3). Rainfall also affected the SMP, and there were three continuous rainfall events: 1-14 June, 22 July to 5 August and 3-11 November in 2012 that delivered 143, 380 

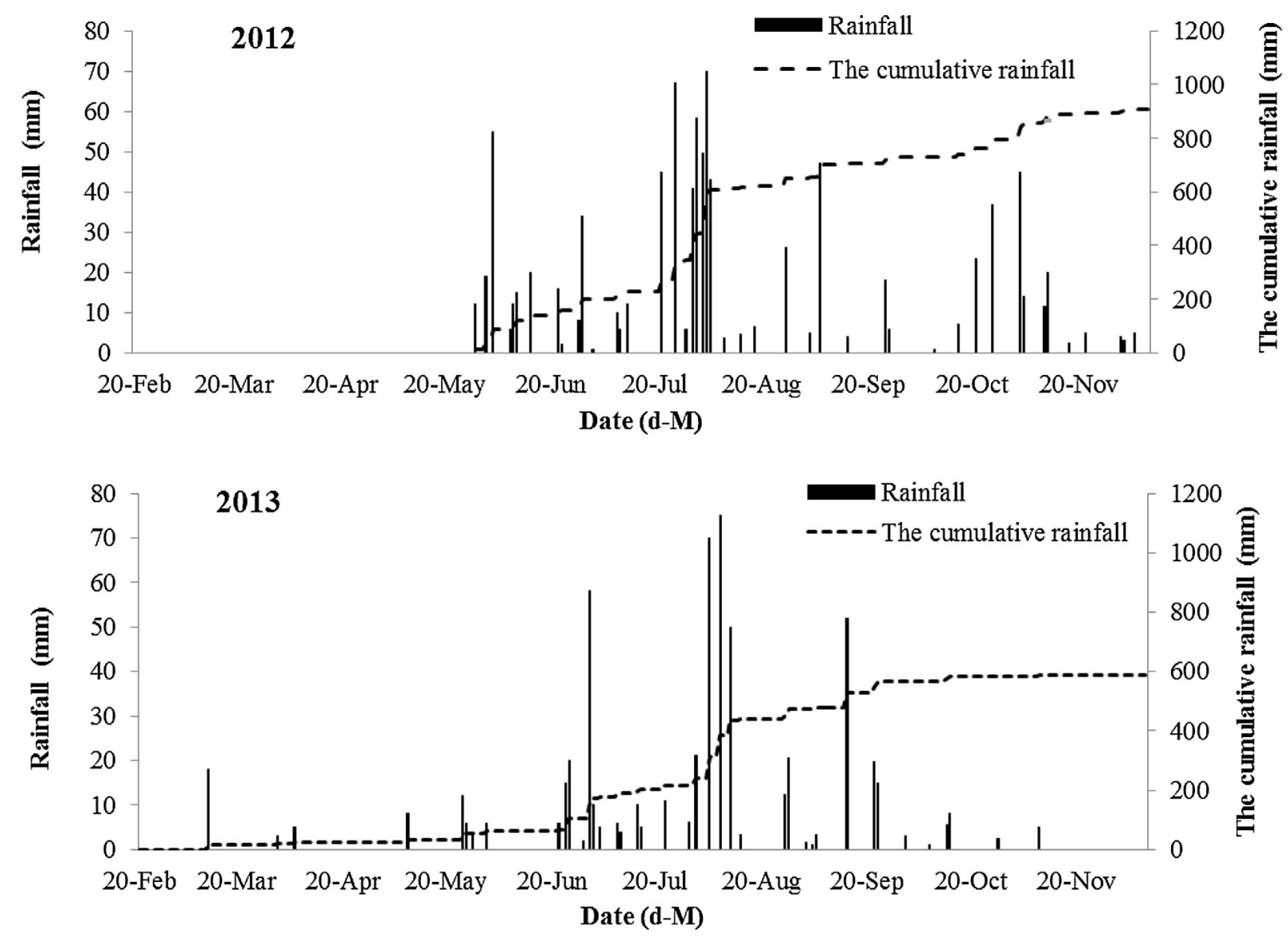

Fig. 2. Rainfall and cumulative rainfall during the growing seasons of the willows in 2012 and 2013.

and $91 \mathrm{~mm}$, respectively. During the continuous rainfall events, the SMPs were always above the designed SMP values for all treatments. This phenomenon also appeared during 24 June to 2 July and 1-11 August in 2013 (Fig. 3).

\subsubsection{Irrigation}

The number of irrigations and irrigation water depths for each treatment are shown in Table 2. During two growing seasons, the control treatment ( $\mathrm{C} 1)$ had the largest number of irrigations and the
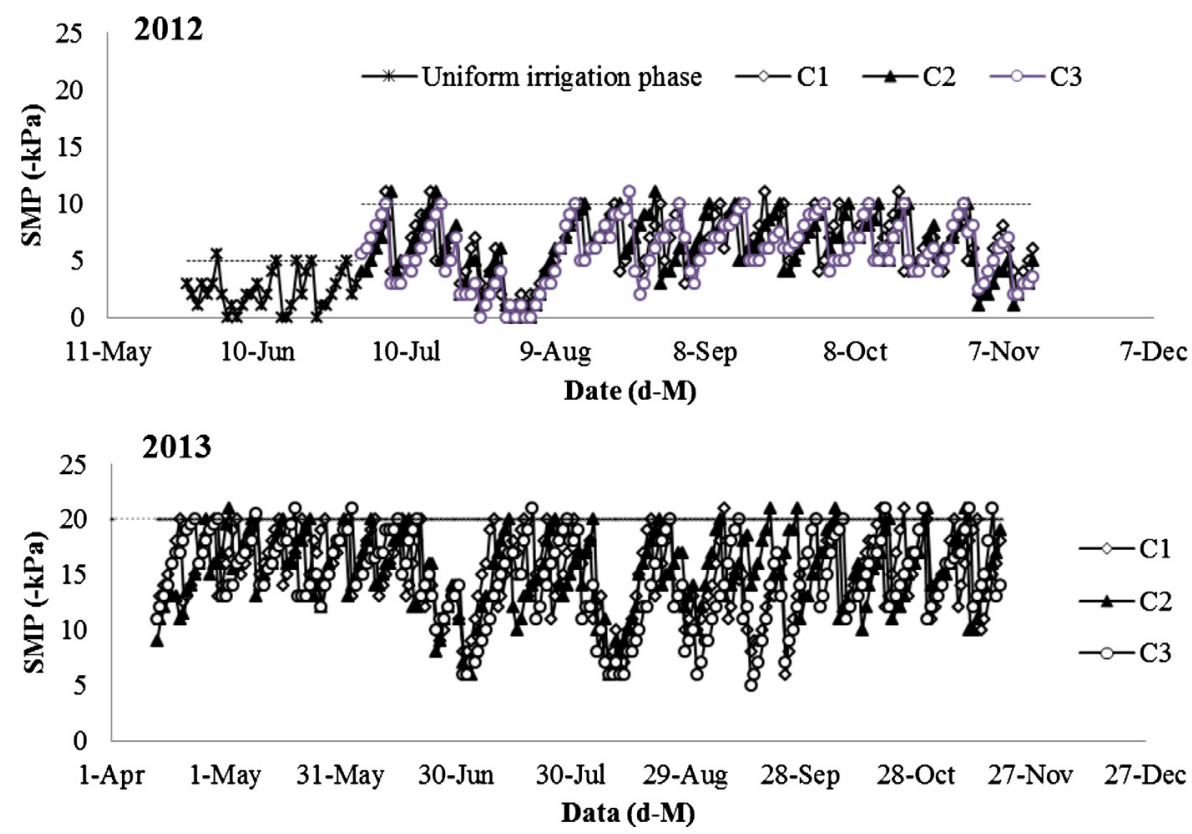

Fig. 3. The SMP (soil matric potential) at $20 \mathrm{~cm}$ depth under the emitters, during the growing seasons of the willows in 2012 and 2013. 
Table 3

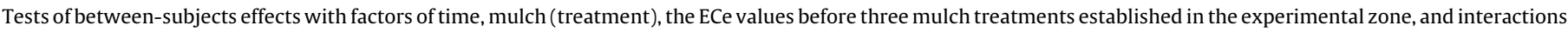

\begin{tabular}{|c|c|c|c|c|c|c|c|}
\hline Dependent variable & Soil depth $(\mathrm{cm})$ & Source & Type III sum of squares & $\mathrm{d} f$ & Mean square & $F$ & Sig. \\
\hline \multirow{9}{*}{$\mathrm{EC}$} & \multirow{4}{*}{$0-60$} & Time & 6.480 & 1 & 6.480 & 10.068 & 0.009 \\
\hline & & Mulch & 0.394 & 2 & 0.197 & 0.306 & 0.743 \\
\hline & & $\mathrm{ECe}$ & 0.307 & 1 & 0.307 & 0.477 & 0.504 \\
\hline & & Time*mulch & 0.223 & 2 & 0.112 & 0.173 & 0.843 \\
\hline & & & & & & & \\
\hline & \multirow{4}{*}{$0-100$} & Time & 0.347 & 1 & 0.347 & 0.554 & 0.472 \\
\hline & & Mulch & 1.848 & 2 & 0.924 & 1.474 & 0.271 \\
\hline & & $\mathrm{ECe}$ & 0.166 & 1 & 0.166 & 0.265 & 0.617 \\
\hline & & Time*mulch & 0.401 & 2 & 0.201 & 0.320 & 0.733 \\
\hline
\end{tabular}

maximum amount of irrigation water; and followed by the black shading net mulch treatment (C2) and, the lowest value existed for the straw mulch treatment (C3). Seasonal applied irrigation water had the same order: $\mathrm{C} 1>\mathrm{C} 2>\mathrm{C} 3$. Compared to the $\mathrm{C} 1$ treatment, the amount of irrigation water for C2 and C3 treatments had decreased by 5\% and $12 \%$ in 2012 and $15 \%$ and $27 \%$ in 2013 , respectively.

Mulches can prevent soil water evaporation and control weeds grow, which resulted in less irrigation water was applied for the C2 and C3 treatments than the C1 treatment. The field survey found that $>80 \%$ of the soil in the $\mathrm{C} 1$ treatment plots was covered by weeds at the end of both growing seasons and the living weeds could compete with willows for water. While the weeds were controlled well by the black shading net and straw mulch, with only sporadic plants distributed in both C2 and C3 treatment plots. The differences in use of irrigation water between the $\mathrm{C} 1$ and $\mathrm{C} 2$ treatments may be due to different thickness of mulch material. The thickness of black shading net laid on the ground for the $\mathrm{C} 2$ treatment was far thinner than the straw layer in the C3 treatment plots, and the thicker mulch layer resulted in more irrigation water and rainfall stored in soil profile and less soil water lost for evaporation (Unger, 1978; Sun et al., 2012b). The field survey found that the topsoil in contact with black shading net in the $\mathrm{C} 2$ treatment plots dried easier after irrigation than that in the $\mathrm{C} 3$ treatment. Thus under the same climatic condition, the straw mulch had the best effect on irrigation water saving.

\subsection{Spatial distribution of ECe}

\subsubsection{ECe spatial distribution}

The ECe before the willows transplanting was used as the initial soil ECe value for each SMP treatment (Fig. 4A). The salt was uniform in the whole soil profile because the soil sample was obtained after deep-plowing and was mixed very well. The initial average ECe values for the root zone $(0-60 \mathrm{~cm})$ and for the whole soil profile $(0-100 \mathrm{~cm})$ were 26.3 and $26.1 \mathrm{dS} \mathrm{m}^{-1}$, respectively.

The low salinity zone in the soil profile enlarged with time from the top soil layer to the bottom (Fig. 5A-D) during the mulch treatment period. When the uniform irrigation period finished (1 July 2012, Fig. 5A), the ECe in the root zone was $4.3,3.4$ and $3.6 \mathrm{dS} \mathrm{m}^{-1}$ for the $\mathrm{C} 1-\mathrm{C} 3$ treatments, respectively, and the desalinization rate of the $\mathrm{C} 1-\mathrm{C} 3$ treatments was $83.8 \%, 87.0 \%$ and $86.4 \%$, respectively. The ECe in the whole soil profile for the C1-C3 treatments was 8.1, 8.5 and $7.2 \mathrm{dS} \mathrm{m}^{-1}$, and decreased by $69 \%, 67 \%$ and $72 \%$, respectively, compared to the initial salinity (Fig. 4A). Under the same amount of irrigation, the different ECe values for all treatments were due to spatial variability of soil texture. The obvious salt reduction during the uniform irrigation period was mainly affected by $190 \mathrm{~mm}$ of irrigation and $210 \mathrm{~mm}$ of rainfall (Table 2). In this period, the experimental zone was not mulched, the root zone salinity decreased and had no limit on willows growth, but the soil salinity in the whole soil profile was still beyond the salt threshold of willow, so continuous irrigation must be applied to further leach soil salinity.

The average ECe values of the root zone for the $\mathrm{C} 1-\mathrm{C} 3$ treatments were further decreased to $2.6,2.0$ and $1.8 \mathrm{dS} \mathrm{m}^{-1}$, respectively, at the end of 2012 (Fig. 5B); 3.1, 2.2 and $1.7 \mathrm{dS} \mathrm{m}^{-1}$, respectively, at the beginning of 2013 (Fig. 5C) and, $1.7,1.7$ and $1.5 \mathrm{dS} \mathrm{m}^{-1}$, respectively, at the end of 2013 (Fig. 5D). Compared to the initial ECe (Fig. 4A), the average soil salinity for the $\mathrm{C} 1-\mathrm{C} 3$ treatments had decreased by $94 \%, 93 \%$ and $94 \%$, respectively, after 2 years. The average ECe values of the whole soil profile for the $\mathrm{C} 1-\mathrm{C} 3$ treatments further decreased to $5.9,4.5$ and $4.6 \mathrm{dS} \mathrm{m}^{-1}$, respectively, at the end of 2012 (Fig. 5B); and 3.5, 3.2 and 3.1 $\mathrm{dS} \mathrm{m}^{-1}$, respectively, at the end of 2013 (Fig. 5D) Compared to the initial ECe (Fig. 4A), the average ECe value for the C1-C3 treatments (Fig. 5D) had decreased by $87 \%, 88 \%$ and $88 \%$, respectively.

The mean soil salinity values (ECe) after the uniform irrigation stage were different for all mulch treatments due to soil spatial variability and it may have affected the treatment values, so the contribution of time, mulch, the ECe value and the interactions of time $\times$ mulch on the change of soil salinity during 2012 and 2013 were evaluated (Table 3 ). The analysis showed that remarkably significant $(p<0.01)$ difference for soil salinity in the root zone $(0-60 \mathrm{~cm})$ with respect to time, but no significant $(p \geq 0.05)$ differences for mulch, ECe, time $\times$ mulch. For whole soil profile $(0-100 \mathrm{~cm})$, all factors had no significant $(p \geq 0.05)$ differences on soil salinity reduction. The results above shown the mulch treatment had no obvious effect on soil salinity reduction.

The change of salinity in the upper soil layer $(0-20 \mathrm{~cm})$ after a winter (from 2 November 2012 to 20 March 2013) was used to estimate the effect of the mulches on salt accumulation in early
(A)

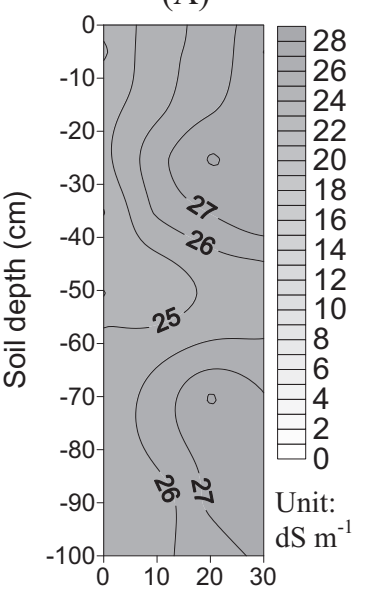

Distance from emitter $(\mathrm{cm})$
(B)

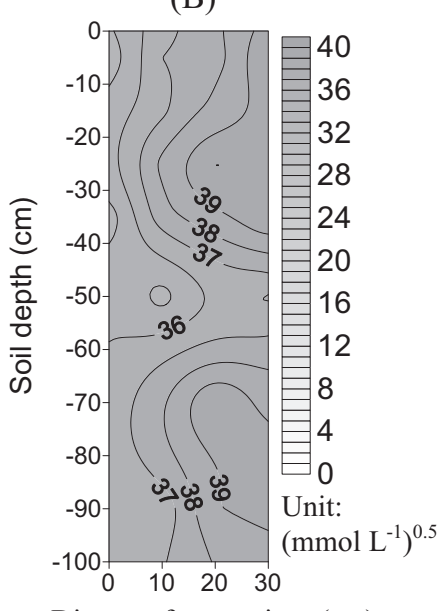

Distance from emitter $(\mathrm{cm})$
Fig. 4. The spatial distribution of the soil ECe (electrical conductivity of saturated paste extracts) (A), and soil SAR (sodium adsorption ratios) (B) in the soil profile for all treatments before the willows were established in May 2012. 

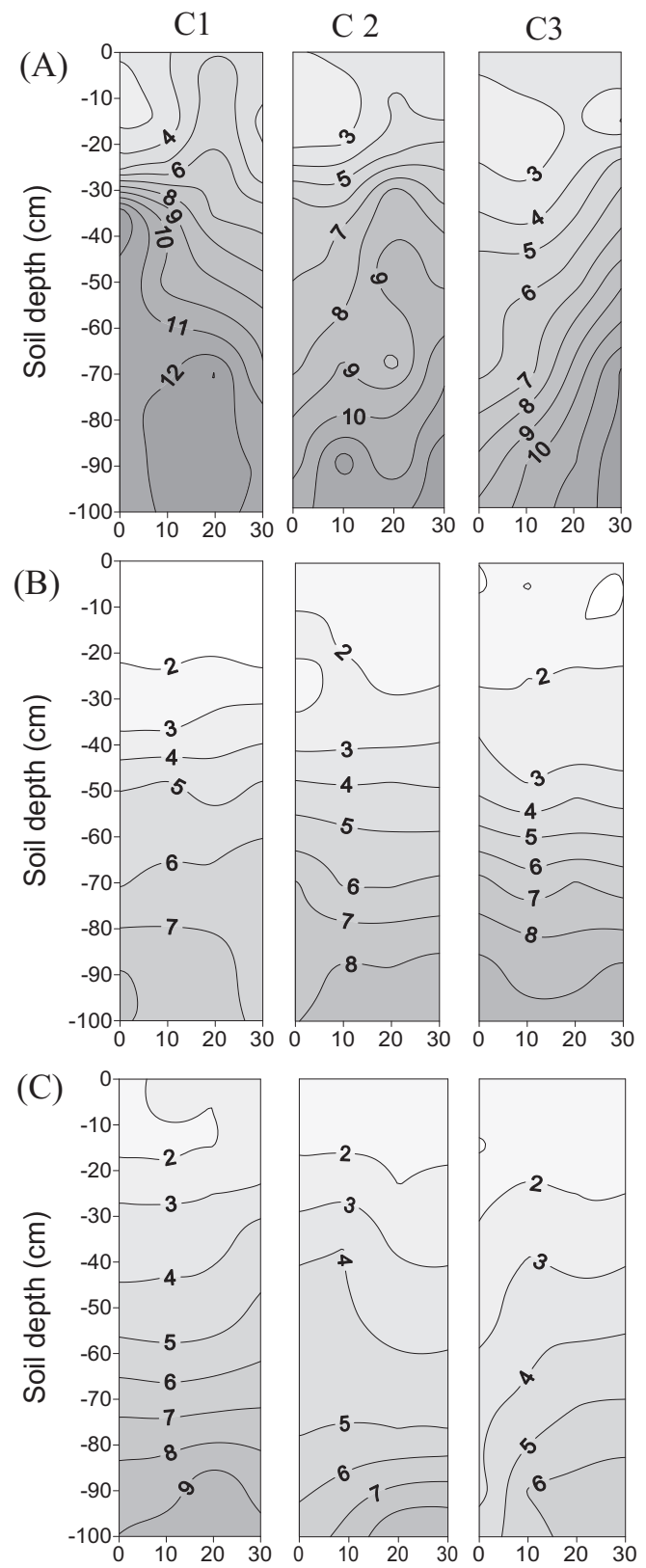

\section{(D)}

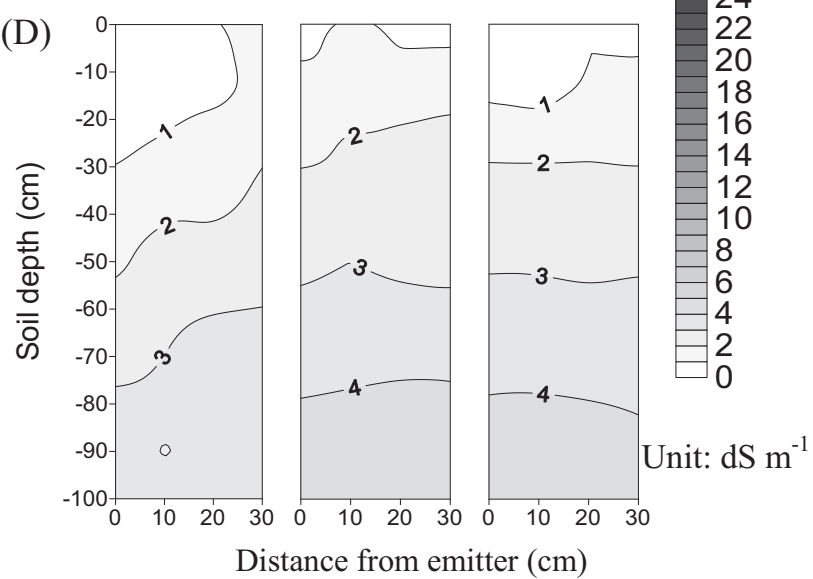

Fig. 5. The spatial distribution of the soil ECe (electrical conductivity of saturated paste extracts) in the soil profile after uniform irrigation (A) in July 2012, at the end of experiment (B) in 2012, and at the beginning (C) and at the end of experiment (D) in 2013.
Table 4

The change of ECe $\left(\mathrm{dS} \mathrm{m}^{-1}\right)$ in the top soil layer $(0-20 \mathrm{~cm}$ ) after a winter (2 November 2012 to 20 March 2013) for different treatments.

\begin{tabular}{|c|c|c|c|}
\hline \multirow[t]{2}{*}{ Treatment } & \multicolumn{3}{|c|}{ Soil depth } \\
\hline & $0-10 \mathrm{~cm}$ & $10-20 \mathrm{~cm}$ & Average $(0-20 \mathrm{~cm})$ \\
\hline $\mathrm{C} 1$ & $-0.05^{b}$ & $-0.63^{b}$ & $-0.34^{\mathrm{b}}$ \\
\hline $\mathrm{C} 2$ & $0.01^{\mathrm{b}}$ & $0.18^{\mathrm{ab}}$ & $0.09^{b}$ \\
\hline C3 & $0.85^{a}$ & $0.75^{a}$ & $0.80^{\mathrm{a}}$ \\
\hline
\end{tabular}

Values followed by different letters in a column differ significantly at $p<0.05$.

spring (the negative value represents salt accumulation and the positive value shows salt reduction, Table 4). After a winter, the soil salinity for the $\mathrm{C} 1$ treatment accumulated for both $0-10$ and $10-20 \mathrm{~cm}$ soil layers and was significantly different $(p<0.05)$ to the C3 treatment at $0-20 \mathrm{~cm}$ depth. The soil salinity for the C2 and C3 treatments decreased and the $\mathrm{C} 2$ treatment had a very slight variation in $0-20 \mathrm{~cm}$ depth. There was significantly difference $(p<0.05)$ between the $\mathrm{C} 2$ and $\mathrm{C} 3$ treatments at $0-10$ and $0-20 \mathrm{~cm}$ depth. The results above shown the straw mulch could decrease the risk of salt accumulation on the surface soil in early spring, compared to the other treatments.

The results indicated that after two growing seasons, the salinity in the root zone and the whole soil profile for all treatments had decreased to below the salt threshold of willow, and so there was not salt stress on willow growth. The salinity reduction was mainly driven by the rainfall and the strategy of drip irrigation, and the different mulch materials had no obviously effect on salt reduction but the straw mulch could decrease the risk of salt accumulation on the surface soil in early spring.

\subsection{Spatial distribution of SAR}

The spatial distribution of SAR in the soil profile was closely related to the ECe levels, and the soil zone with the lowest ECe value corresponded to the lowest SAR. Similarly the soil zone with the highest salt levels corresponded to the highest SAR (Figs. 4B and 6A-D). The initial soil SAR was $37.7\left(\mathrm{mmol} \mathrm{L}^{-1}\right)^{0.5}$ for the root zone and $37.5\left(\mathrm{mmol} \mathrm{L}^{-1}\right)^{0.5}$ for the whole soil profile (Fig. 4B).

When the uniform irrigation stage finished (Fig. 6A), the SAR distribution was similar to the soil ECe distribution (Fig. 5A), and the highest SAR was in the $60-100 \mathrm{~cm}$ soil layer and the lowest SAR was in the upper soil layers. In this stage, the average SAR values in root zone for the $\mathrm{C} 1-\mathrm{C} 3$ treatments decreased to 8.5, 7.4 and $7.6\left(\mathrm{mmol} \mathrm{L}^{-1}\right)^{0.5}$, respectively; and the corresponding average SAR values for the whole root profile decreased to $13.5,14.1$ and $12.4\left(\mathrm{mmol} \mathrm{L}^{-1}\right)^{0.5}$, respectively. Compared to the initial SAR value (Fig. 4B), the rate of SAR reduction for the C1-C3 treatments was $77 \%, 80 \%$ and $80 \%$ in root zone and $64 \%, 62 \%$ and $67 \%$ in whole soil profile, respectively. The different rate of SAR reduction was due to spatial variability of soil texture and, rainfall and irrigation resulted in a large value of SAR reduction ratio.

The average SAR values in root zone for the C1-C3 treatments were $6.4,5.5$ and $5.2\left(\mathrm{mmol} \mathrm{L}^{-1}\right)^{0.5}$, respectively, at the end of 2012 (Fig. 6B); 6.9, 5.8 and $5.2\left(\mathrm{mmol} \mathrm{L}^{-1}\right)^{0.5}$, respectively, at the beginning of 2013 (Fig. 6C) and, 5.1, 5.2 and $4.9\left(\mathrm{mmol} \mathrm{L}^{-1}\right)^{0.5}$, respectively, at the end of 2013 (Fig. 6D). The average SAR values in whole soil profile for the C1-C3 treatments were 10.7, 8.8 and $9.0\left(\mathrm{mmol} \mathrm{L}^{-1}\right)^{0.5}$, respectively, at the end of 2012 (Fig. 6B); $11.2,8.5$ and $7.3\left(\mathrm{mmol} \mathrm{L}^{-1}\right)^{0.5}$, respectively, at the beginning of 2013 (Fig. 6C) and, 7.5, 7.2 and $7.0\left(\mathrm{mmol} \mathrm{L}^{-1}\right)^{0.5}$, respectively, at the end of 2013 (Fig. 6D). By the end of 2013, the average soil SAR values for the C1-C3 treatments had decreased by $86 \%, 86 \%$ and $87 \%$ for the root zone and by $80 \%, 81 \%$ and $81 \%$ for the whole soil 

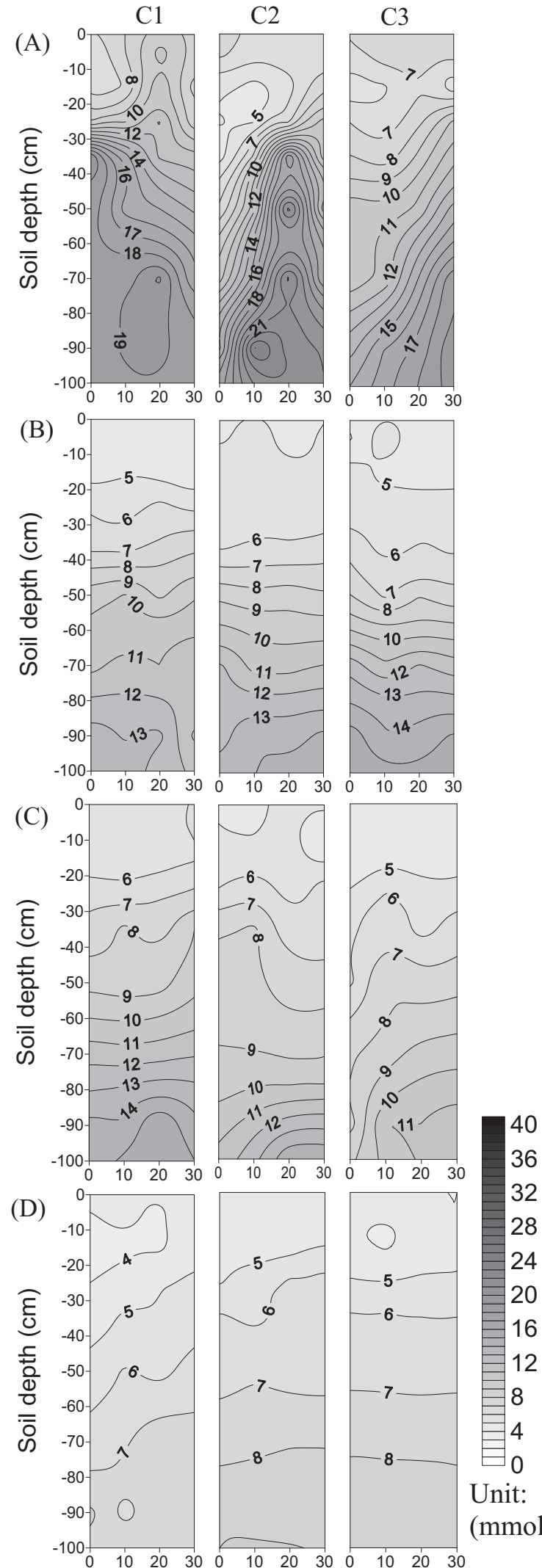

28

24

24

20

16

12

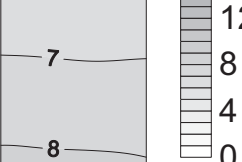

Unit: $\left(\mathrm{mmol} \mathrm{L}^{-1}\right)^{0.5}$

Distance from emitter $(\mathrm{cm})$

Fig. 6. The spatial distribution of the soil SAR (sodium adsorption ratios) in the soil profile after uniform irrigation (A) in 2012, at the end of experiment (B) in 2012, and at the beginning (C) and at the end of experiment (D) in 2014. profile, respectively. The average soil SAR values for all treatments decreased annually, compared to the initial average SAR values.

After two growing seasons, there was an outstanding reduction of SAR for all treatment and the SAR values were lower than 13.0 $\left(\mathrm{mmol} \mathrm{L}^{-1}\right)^{0.5}$ (Holmes, 1982), which shown no sodium hazard on willow growth.

\subsection{Willow growth characteristics}

Table 5 shows the effect of the different mulch treatments on the survival ratio and growth indices of the willow after 2 years. As a salt-tolerant plant, willow has been planted widely in the urban green belt on coastal saline soil. The survival ratio was not significantly different among the treatments $(p \geq 0.05)$. Plant height, stem diameter and crown diameter were remarkably affected by the different mulch treatments. Compared to the $\mathrm{C} 1$ treatment, the plant height, crown diameter and stem diameter for the $\mathrm{C} 2$ and $\mathrm{C} 3$ treatments were greater - likely due to weeds in the C1 treatment plots competing with the willows for fertilizer and water. Compared to the $\mathrm{C} 2$ treatment, the $\mathrm{C} 3$ treatment had relatively larger values of the average crown diameter and stem diameter; it means the straw mulch resulted in better growth characteristics of willows than the other two treatments.

\subsection{Investment cost}

\subsubsection{Water and labors cost}

Table 6 shows the water and labors cost for all treatments in 2012 and 2013. Cost of water was closely related with the amount of irrigation. The $\mathrm{C} 1$ treatment consumed the largest irrigation water, then followed by the $\mathrm{C} 2$ and $\mathrm{C} 3$ treatment during 2 years (Table 2 ), so the list of the cost was $\mathrm{C} 1>\mathrm{C} 2>\mathrm{C} 3$ treatment.

The cost of labors was associated with integrated factors as the irrigation management, weed control, willows transplant, layout of mulching material and other labor cost, etc.

During irrigation, it needed labors to run drip irrigation system, meanwhile, the fertilizer was added into the water by labors and flowed with water from drip irrigation system to plant root. So the cost of irrigation management was mainly affected by the number of irrigations. So the C1 treatment had the largest cost and the C3 treatment had the least (Table 2). Compared to the total labors cost, the cost of irrigation management for all treatments had accounted to $39-46 \%$ in 2012 and $44-56 \%$ in 2013.

In 2012, the black shading net was laid in the C2 treatment plots easier than the straw in the $\mathrm{C} 3$ treatment plots, so the cost for layout of mulching material was lower for the $\mathrm{C} 2$ than the $\mathrm{C} 3$ treatment. In 2013, there was no cost because the mulching material laid in 2012 for all treatments was not changed in 2013.

Sporadic weeds grew in the C2 and C3 treatment plot resulted in the low cost of weed control in both growing seasons. The same number of plants in three treatment plots resulted in the same cost of willows transplanting, plant prune and disease control. Compared to the total labors cost, the cost of plant prune and disease control accounted for 27-28\% in 2012 and 45-49\% in 2013.

Generally, the single largest expenditure is for tree trimming, followed by tree planting (McPherson et al., 2000). In this study, the most important thing was to rapid leach high soil salinity after willows transplanting. Drip irrigation with its characteristic of applying water at high frequency and low discharge rate could effectively reduce soil salinity (Goldberg et al., 1976). High frequency resulted in high cost of irrigation management. So the single largest labors expenditure in this study was for irrigation management in 2 year except the C3 treatment in 2013. Moreover, with further leaching of salt, the saline soils will be reclaimed, and the soil matric potential could be controlled at lower value to make full use of the rainfall (the local mean annual precipitation is 
Table 5

The survival ratio, growth indices of the willows after 2 years.

\begin{tabular}{|c|c|c|c|c|}
\hline Treatments & Survival ratio (\%) & Plant height (m) & Average crown diameter $(\mathrm{m})$ & Stem diameter $(\mathrm{cm})$ \\
\hline $\mathrm{C} 1$ & $91^{\mathrm{a}}$ & $6.4^{\mathrm{a}}$ & $3.2^{\mathrm{a}}$ & $7.7^{\mathrm{a}}$ \\
\hline $\mathrm{C} 2$ & $100^{\mathrm{a}}$ & $6.9^{\mathrm{b}}$ & $3.5^{\mathrm{b}}$ & $8.4^{\mathrm{b}}$ \\
\hline $\mathrm{C} 3$ & $100^{\mathrm{a}}$ & $6.9^{\mathrm{b}}$ & $3.6^{\mathrm{b}}$ & $8.9^{c}$ \\
\hline
\end{tabular}

Values followed by different letters in a column differ significantly at $p<0.05$.

Table 6

The detail information of the water and labors cost for each treatment in 2012 and 2013.

\begin{tabular}{|c|c|c|c|c|c|c|c|c|c|c|}
\hline \multirow[t]{2}{*}{ Year } & \multirow[t]{2}{*}{ Treatments } & \multicolumn{3}{|c|}{ Water cost $\left(\$ \mathrm{ha}^{-1}\right)$} & \multicolumn{6}{|c|}{ Labors cost $\left(\$\right.$ ha $\left.^{-1}\right)$} \\
\hline & & $\begin{array}{l}\text { Irrigation } \\
\text { water } \\
\left(\mathrm{m}^{3} \mathrm{ha}^{-1}\right)\end{array}$ & $\begin{array}{l}\text { Water } \\
\text { price } \\
\left(\$ \mathrm{~m}^{-3}\right)\end{array}$ & $\begin{array}{l}\text { Total water } \\
\text { cost } \\
\left(\$ \mathrm{ha}^{-1}\right)\end{array}$ & $\begin{array}{l}\text { Irrigation } \\
\text { management } \\
\left(\$ \mathrm{ha}^{-1}\right)\end{array}$ & $\begin{array}{l}\text { Weed } \\
\text { control } \\
\left(\$ h^{-1}\right)\end{array}$ & $\begin{array}{l}\text { Willows } \\
\text { transplant } \\
\left(\$ \mathrm{ha}^{-1}\right)\end{array}$ & $\begin{array}{l}\text { Layout of } \\
\text { mulching } \\
\text { material }\left(\$ h a^{-1}\right)\end{array}$ & $\begin{array}{l}\text { Plant prune } \\
\text { and disease } \\
\text { control }\left(\$ \mathrm{ha}^{-1}\right)\end{array}$ & $\begin{array}{l}\text { Total labors } \\
\text { cost }\left(\$ h a^{-1}\right)\end{array}$ \\
\hline \multirow{3}{*}{2012} & $\mathrm{C} 1$ & 4300 & 1.63 & 7009 & 2436 & 0 & 1360 & 0 & 1500 & 5296 \\
\hline & $\mathrm{C} 2$ & 4100 & 1.63 & 6683 & 2323 & 113 & 1360 & 227 & 1500 & 5522 \\
\hline & $\mathrm{C} 3$ & 3800 & 1.63 & 6194 & 2153 & 227 & 1360 & 340 & 1500 & 5579 \\
\hline \multirow{3}{*}{2013} & $\mathrm{C} 1$ & 3300 & 1.63 & 5379 & 1870 & 0 & 0 & 0 & 1500 & 3370 \\
\hline & $\mathrm{C} 2$ & 2800 & 1.63 & 4564 & 1586 & 113 & 0 & 0 & 1500 & 3200 \\
\hline & $\mathrm{C} 3$ & 2400 & 1.63 & 3912 & 1360 & 227 & 0 & 0 & 1500 & 3086 \\
\hline
\end{tabular}

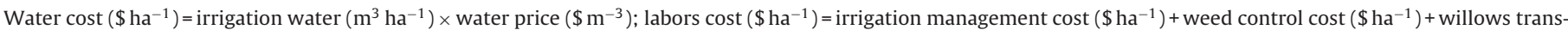
planting cost $\left(\$ \mathrm{ha}^{-1}\right)+$ mulch material laying cost $\left(\$ \mathrm{ha}^{-1}\right)+$ other cost $\left(\$ \mathrm{ha}^{-1}\right)$.

$607 \mathrm{~mm}$ ), then the cost of irrigation management could be further decreased, it resulted in the single largest labor cost for tree trimming.

The cost of irrigation management for the $\mathrm{C} 3$ treatment was the least, but the sum cost of the weed control and the layout of mulching material were larger than that of the C1 and C2 treatments, so the total labors cost for the $\mathrm{C} 3$ treatment was largest in 2012. The total labors cost in 2013 was mainly affected by the cost of irrigation management, so the $\mathrm{C} 3$ treatment had the lowest total labors cost, compared to the $\mathrm{C} 1$ and $\mathrm{C} 2$ treatments.

\subsubsection{Investment cost}

Table 7 shows the total investment cost for the mulch treatments in 2012 and 2013. With the same willow plants cultivated in the same size of the field area, the costs of irrigation equipment, willows, soil preparation, gravel and sand, fertilizer, pesticide and other materials were the same for all treatments.

Compared to the total investment cost in 2012, the sum of willows cost, soil preparation cost, gravel and sand cost for the C1-C3 treatments was accounted to $76 \%, 73 \%$ and $76 \%$, respectively. In this study, the plant density of willows was $9 \mathrm{~m}^{2}$ per tree; the stem diameter size of willows was large with $7 \mathrm{~cm}$ and the price was $25.5 \$$ per tree (local price), so the willows cost was high. If choose small seeding with less than $2 \mathrm{~cm}$ of stem diameter, the price can reduce to $0.5 \$$ per tree (local price). Under the same plant density, the cost could decreased from $28,326 \$ /$ ha to $550 \$ /$ ha.

The cost of fertilizer, pesticide and other materials in 2012 was higher than that in 2013 because many wooden poles were bought to fix the willows to against the wind after willows transplanted. The cost of drip irrigation system was same for all treatments during two growing seasons. The main part of drip irrigation system could be used for many years, but the laterals inlaid with emitters were changed year by year, so the cost of drip irrigation system in 2012 was higher than that in 2013.

The price of the different mulch materials differed. The rice production area was close to the experiment zone resulted in low straw price. The price of black shading net per square meter was about six times that of straw.

In 2012, the cost of water and labors for the C1-C3 treatments was different (Table 6) and could affect the total investment cost, but the different mulch material price was main reason response to the difference of the total investment cost among three treatments, and the highest mulch material cost for the $\mathrm{C} 2$ treatment brought the largest total investment cost, while the $\mathrm{C} 1$ and $\mathrm{C} 3$ treatments had almost same investment. In 2013, the total investment cost was mainly affected by the water cost, followed by labors cost, and the C3 treatment had the lowest total investment cost in 2013 among the $\mathrm{C} 1-\mathrm{C} 3$ treatments. Comparing the total investment cost between 2 years, the cost in 2013 was about a 10th of that in 2012 .

Table 7

Total investment cost for the each treatment in 2012 and 2013.

\begin{tabular}{|c|c|c|c|c|c|c|c|c|c|c|}
\hline Year & Treatments & $\begin{array}{l}\text { Water } \\
\text { cost } \\
\left(\$ h a^{-1}\right)\end{array}$ & $\begin{array}{l}\text { Labors } \\
\text { cost } \\
\left(\$ \mathrm{ha}^{-1}\right)\end{array}$ & $\begin{array}{l}\text { Mulch material } \\
\text { cost }\left(\$ h^{-1}\right)\end{array}$ & $\begin{array}{l}\text { Drip irrigation } \\
\text { system cost } \\
\left(\$ \mathrm{ha}^{-1}\right)\end{array}$ & $\begin{array}{l}\text { Willows } \\
\text { cost } \\
\left(\$ \mathrm{ha}^{-1}\right)\end{array}$ & $\begin{array}{l}\text { Soil } \\
\text { preparation } \\
\text { cost }\left(\$ h a^{-1}\right)\end{array}$ & $\begin{array}{l}\text { Gravel and } \\
\text { sand cost } \\
\left(\$ h a^{-1}\right)\end{array}$ & $\begin{array}{l}\text { Fertilizer, pesticide } \\
\text { and other materials } \\
\text { cost }\left(\$ \mathrm{ha}^{-1}\right)\end{array}$ & $\begin{array}{l}\text { Total } \\
\text { investment } \\
\text { cost }\left(\$ h a^{-1}\right)\end{array}$ \\
\hline \multirow{3}{*}{2012} & $\mathrm{C} 1$ & 7009 & 5269 & 0 & 9785 & 28,326 & 26,105 & 24,474 & 5093 & $106,088^{a}$ \\
\hline & $\mathrm{C} 2$ & 6683 & 5495 & 4895 & 9785 & 28,326 & 26,105 & 24,474 & 5093 & $110,884^{\mathrm{a}}$ \\
\hline & $\mathrm{C} 3$ & 6194 & 5552 & 816 & 9785 & 28,326 & 26,105 & 24,474 & 5093 & $106,372^{a}$ \\
\hline \multirow{3}{*}{2013} & $\mathrm{C} 1$ & 5379 & 3342 & 0 & 489 & 0 & 0 & 0 & 1592 & $10,830^{\mathrm{a}}$ \\
\hline & $\mathrm{C} 2$ & 4564 & 3173 & 0 & 489 & 0 & 0 & 0 & 1592 & $9845^{\mathrm{b}}$ \\
\hline & $\mathrm{C} 3$ & 3912 & 3059 & 0 & 489 & 0 & 0 & 0 & 1592 & $9080^{c}$ \\
\hline
\end{tabular}

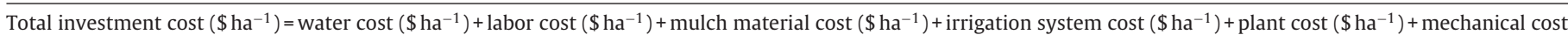
$\left(\$ h^{-1}\right)+$ gravel and sand cost $\left(\$ h^{-1}\right)+$ fertilizer, pesticide and other materials cost $\left(\$\right.$ ha $\left.^{-1}\right)$. Values in the same letter are not significantly different at $p<0.05$. 
The results above shown that under the reclamation method for vegetation construction on the coastal saline soil in this study, the main investment was used to pay the cost of willows, soil preparation, gravel and sand at the beginning of willows transplanting, then the mulch material cost, water cost and labors cost as the maintenance costs were the main factors to affected the consequent total investment cost.

At present, the main method of vegetation rehabilitation is to replace saline with non-saline soil for depths of $0-100 \mathrm{~cm}$, and this has been widely used in coastal saline areas (Sun et al., 2012a). According to market survey, the cost of landscaping in the research region is up to $250,000-480,000 \$ /$ ha. Pan et al. (2010) indicated that with different engineering technologies, e.g. sand layer, drainpipe, soil mixed by non-saline and saline soil, the cost decreased to $170,000-260,000 \$ /$ ha without the seedling cost. Compared to the cost reported by Pan et al. (2010), the investments for all treatments in this study decreased by nearly $41-65 \%$. If choose the small seedling, the cost decreased more. Reduction of the quantity of non-saline soil used for landscape was the main reason for the cost reduction. McPherson et al. (2000) indicated that the average annual maintenance costs for public trees were estimated to range from 21 to 28 \$ per tree, but the costs in this study was $9-10 \$$ per tree, it may be caused by different domestic price level between America and China.

\section{Conclusions}

Over the 2-year study, the irrigation water amount was affected by mulches, and straw mulch had the lowest numbers of irrigations and amounts in both growing seasons. Compared to the control treatment, the amount of irrigation for straw mulch treatment saved $12 \%$ in 2012 and $27 \%$ in 2013.

Soil salt reduction in the early salt-leaching period was closely associated with the rainfall and the strategy of drip irrigation. During the winter and spring, the mulches could effectively restrain salt accumulation in early spring, especially straw mulch. The salinity and SAR in the root zone and the whole soil layer significantly decreased for all the treatments after two growing seasons, and the salinity was below the salt threshold of willow so that plant growth was not limited by salt stress. The different mulches had significant effects on plant height, crown diameter and stem diameter but no effect on survival ratio of willows. The best plant growth characteristic was for the straw mulch treatment at the end of the two growth years. In addition, the investment cost analysis showed that the black shading net mulch had the highest investment in 2012, due to the high mulch material price. The straw mulch and the control treatments had the same total investment cost in 2012, and then the straw mulch had the lowest investment in 2013 due to the lowest water and labors cost. The investment cost was high in 2012 but decreased by $90 \%$ in 2013 . Owing to the willow as a perennial plant, the straw mulch was the best choice for investment saving.

From the combined points of reduction in investment cost, water saving and promoting plant growth, and using straw mulch with drip irrigation could help in landscape construction on this coastal saline soil. Furthermore, it should be noted that these conclusions were based on a coastal sandy-loam soil. To assess the practicability of the method to reclaim other soil structure of coastal saline soil (e.g. coastal saline silt soil and clay) in North China, further studies are required.

\section{Acknowledgements}

This study was supported by the National Key Technology R\&D Program of China (Grant Nos. 2013BAC02B02 and 2013BAC02B01), and the Action Plan for the Development of Western China of the Chinese Academy of Sciences (Grant No. KZCX2-XB3-16).

\section{References}

Adams, J.E., 1966. Influence of mulches on runoff erosion and soil moisture depletion. Soil Sci. Soc. Am. Proc. 30, 110-114.

Aragues, R., Medina, E.T., Claveria, I., 2014. Effectiveness of inorganic and organic mulching for soil salinity and sodicity control in a grapevine orchard drip-irrigated with moderately saline waters. Span. J. Agric. Res. 12, 501-508.

Bao, S.D., 2000. Soil and Agricultural Chemistry Analysis. China Agricultural Press, Beijing, pp. 189-192 (in Chinese).

Bresler, E., McNeal, B.L., Carter, D.L., 1982. Saline and Sodic Soils: Principles, Dynamics, Modeling. Springer-Verlag, Berlin, Heidelberg.

Doring, T.F., Brandt, M., Hess, J., Finckh, M.R., Saucke, H., 2005. Effects of straw mulch on soil nitrate dynamics, weeds, yield and soil erosion in organically grown potatoes. Field Crops Res. 94, 238-249.

Goldberg, D., Gornat, B., Rimon, D.E., 1976. Drip Irrigation - Principles, Design and Agricultural Practices. Drip Irrigation Scientific Publications, Israel

Hanson, B.R., May, D.E., Simunek, J., Hopmans, J.W., Hutmacher, R.B., 2009. Drip irrigation provides the salinity control needed for profitable irrigation of tomatoes in the San Joaquin Valley. Calif. Agric. 63, 131-136.

Holmes, J.C., 1982. Modern irrigated soils - James, DW, Hanks, RJ, Jurinak, JJ. Crop Res. 22, 125-126.

Jiao, Y.P., kang, Y.H., Wan, S.Q., Sun, Z.J., Liu, W., Dong, F., 2008. Effect of soil matric potential on the distribution of soil salt under drip irrigation on saline and alkaline land in arid regions. Trans. CSAE 6, 53-58 (in Chinese with English abstract).

Kang, Y., Wan, S., Jiao, Y., Tan, J., Sun, Z., 2008. Saline soil salinity and water management with tensiometer under drip irrigation. In: Symposia on the Fifth Annua Meeting of Agricultural Land and Water Engineering of Chinese Society of Agricultural Engineering, pp. 124-131.

Kimber, R.W.L., 1973. Phytotoxicity from plant residues. 2. Effect of time of rotting of straw from some grasses and legumes on growth of wheat seedlings. Plant Soil 38, 347-361.

Liu, S.H., Kang, Y.H., Wan, S.Q., Wang, Z.C., Liang, Z.W., Sun, X.J., 2011. Water and salt regulation and its effects on Leymus chinensis growth under drip irrigation in saline-sodic soils of the Songnen Plain. Agric. Water Manag. 98, 1469-1476.

Maas, E.V., 1986. Salt tolerance of plants. Appl. Agric. Res. 1, 12-26.

Marine Geology Research Center, Institute of Oceanology, CAS, 1985. Bohai Geology. Science Press, Beijing, China, pp. 1-2.

McPherson, E.G., Scott, K.I., Simpson, J.R., Xiao, O.F., Peper, P.J., 2000. Tree Guidelines for Coastal Southern California Communities. Western Center for Urban Forest Research and Education USDA Forest Service, Pacific Southwest Research Station, pp. 1-37.

Ossom, E.M. Pace, P.F. Rhykerd, R.L Rhykerd, C.L, 2001. Effect of mulch on weed infestation, soil temperature, nutrient concentration and tuber yield in Ipomoea batatas (L.) Lam. in Papua New Guinea. Trop. Agric. 78, 144-151.

Pan, D.M., Yuan, W.G., Du, J.C., Guo, S.Y., Zheng, Y.M., He, X.H., 2010. Study on the landscaping technologies for coastal saline-alkali land in Tanghai County of Tangshan City in China. J. Landsc. Res. 2, 1-4.

Ramakrishna, A. Tam, H.M., Wani, S.P., Long, T.D., 2006. Effect of mulch on soil temperature, moisture, weed infestation and yield of groundnut in northern Vietnam. Field Crops Res. 95, 115-125.

Sun, B., Xie, J.C., Wang, N., Li, C.J., 2012b. Effect of straw mulching on change of evaporation and water-salt in the saline soil. J. Soil Water Conserv. 26 , $246-250$.

Sun, J.X., Kang, Y.H., Wan, S.Q., Hu, W., Jiang, S.F., Zhang, T.B., 2012a. Soil salinity management with drip irrigation and its effects on soil hydraulic properties in north China coastal saline soils. Agric. Water Manag. 115 10-19.

Sun, J.X., Kang, Y.H., Wan, S.Q., 2013. Effects of an imbedded gravel-sand layer on reclamation of coastal saline soils under drip irrigation and on plant growth. Agric. Water Manag. 123, 12-19.

Terasaki, H., Fukuhara, T., Ito, M., He, C., 2009. Effects of gravel and date-palm mulch on heat moisture and salt movement in a desert soil. Adv. Water Resour. Hydraul. Eng. 1, 320-325.

Unger, P.W., 1978. Straw-mulch rate effect on soil-water storage and sorghum yield. Soil Sci. Soc. Am. J. 42, 486-491.

Wan, S.Q., Jiao, Y.P., Kang, Y.H., Hu, W., Jiang, S.F., Tan, J.L., Liu, W., 2012. Drip irrigation of waxy corn (Zea mays L. var. ceratina Kulesh) for production in highly saline conditions. Agric. Water Manag. 107, 145.

Wang, R.S., Kang, Y.H., Wan, S.Q., Hu, W., Liu, S.P., Liu, S.H., 2011. Salt distribution and the growth of cotton under different drip irrigation regimes in a saline area. Agric. Water Manag. 100, 58-69.

Wang, Z.Q., Zhu, S.Q., Yu, R.P., et al., 1993. Salt-Affected Soils of China. Science Press, Beijing, pp. 145-146 (in Chinese).

Wu, Y.Y., Liu, R.C., Zhao, Y.G., Li, P.P., Liu, C.Q., 2009. Spatial and seasonal variation of salt ions under the influence of halophytes, in a coastal flat in eastern China. Environ. Geol. 57, 1501-1508.

Xia, J., 2002. A perspective on hydrological base of water security problem and its application study in North China. Progress Geogr. 21, 517-526 (in Chinese with English abstract). 
Xing, L., Guo, H., Zhan, Y., 2013. Groundwater hydrochemical characteristics and processes along flow paths in the north China Plain. J. Asian Earth Sci. 70-71, 250-264.

Zhang, G.H., Liang, Y.L., Liu, C.H., Yan, M.J., Wang, J.Z., 2011. Situation and origin of water resources in short supply in north China plain. J. Earth Sci. Environ. 33, $172-176$.
Zhang, T.B., Kang, Y.H., Wan, S.Q., 2013. Shallow sand-filled niches beneath drip emitters made reclamation of an impermeable saline-sodic soil possible while cropping with Lycium barbarum L. Agric. Water Manag. 119, 54-64.

Zhao, Y.G., Pang, H.C., Wang, J., Huo, L., Li, Y.Y., 2014. Effects of straw mulch and buried straw on soil moisture and salinity in relation to sunflower growth and yield. Field Crops Res. 161, 16-25. 